\title{
Nitric oxides and nitrous oxide fluxes from typical vegetables cropland in China: Effects of canopy, soil properties and field management
}

\author{
Xiaobing Pang ${ }^{\mathrm{a}, *}$, Yujing Mu ${ }^{\mathrm{b}, *}$, Xinqing Lee ${ }^{\mathrm{a}}$, Shuangxi Fang ${ }^{\mathrm{c}}$, Juan Yuan ${ }^{\mathrm{d}}$, Daikuan Huang ${ }^{\mathrm{a}}$ \\ a State Key Laboratory of Environmental Geochemistry, Institute of Geochemistry, CAS, Guiyang 550002, China \\ ${ }^{\mathrm{b}}$ Research Center for Eco-environmental of Sciences, CAS, Beijing 100085, China \\ ${ }^{\mathrm{c}}$ Chinese Academy of Meteorological Sciences, China Meteorological Administration, Beijing 100081, China \\ ${ }^{\mathrm{d}}$ Foreign Languages Faculty, Jiangxi University of Finance E Economics, Nanchang 330013, China
}

\section{A R T I C L E I N F O}

\section{Article history:}

Received 4 May 2008

Received in revised form

8 February 2009

Accepted 8 February 2009

\section{Keywords:}

Nitrous oxide

Nitric oxide

Vegetables cropland

Yangtze River Delta of China

\begin{abstract}
A B S T R A C T
In China, vegetable croplands are characterized by intensive fertilization and cultivation, which produce significant nitrogenous gases to the atmosphere. In this study, nitric oxides ( $\mathrm{NO}_{\mathrm{X}}$ ) and nitrous oxide $\left(\mathrm{N}_{2} \mathrm{O}\right)$ emissions from the croplands cultivated with three typical vegetables had been measured in Yangtze River Delta of China from September 2 to December 16, 2006. The NO fluxes varied in the ranges of 1.6-182.4, 1.4-2901 and 0.5-487 $\mathrm{ng} \mathrm{Nm}^{-2} \mathrm{~s}^{-1}$ with averages of $33.8 \pm 44.2,360 \pm 590$ and $76 \pm 112$ (mean $\pm \mathrm{SD}$ ) $\mathrm{ngNm}^{-2} \mathrm{~s}^{-1}$ for cabbage, garlic, and radish fields $(n=88)$, respectively. $\mathrm{N}_{2} \mathrm{O}$ fluxes from the three vegetable fields were found to occur in pulses and significantly promoted by tillage with average values of 5.8, 8.8, and $4.3 \mathrm{ng} \mathrm{Nm}^{-2} \mathrm{~h}^{-1}$ for cabbage, garlic, and radish crops, respectively. Influence of vegetables canopy on the NO emission was investigated and quantified. It was found that on cloudy days the canopy can only shield NO emission from croplands soil while on sunny days it cannot only prevent NO emission but also assimilate NO through the open leaves stomas. Multiple linear regression analysis indicated that soil temperature was the most important factor in controlling $\mathrm{NO}$ emission, followed by fertilizer amount and gravimetric soil water content. About $1.2 \%, 11.56 \%$ and $2.56 \%$ of applied fertilizers $\mathrm{N}$ were emitted as $\mathrm{NO}-\mathrm{N}$ and $\mathrm{N}_{2} \mathrm{O}-\mathrm{N}$ from the cabbage, garlic and radish plots, respectively.
\end{abstract}

Crown Copyright @ 2009 Published by Elsevier Ltd. All rights reserved.

\section{Introduction}

Agricultural activities have greatly altered the global nitrogen cycle and produced a great deal of nitrogenous gases including nitric oxides ( $\mathrm{NO}$ and $\mathrm{NO}_{2}$ ) and nitrous gas $\left(\mathrm{N}_{2} \mathrm{O}\right)$ through crop cultivation, fertilizer $\mathrm{N}$ application, animal manure composting, burning of agricultural residue, industrial stockbreeding, etc. (Dong et al., 2007; Yan et al., 2003). NOx play a critical role in the chemistry of the lower troposphere, combined with VOCs, by catalyzing the photochemical formation of $\mathrm{O}_{3}$. $\mathrm{NO}_{\mathrm{X}}$ are the important components of photochemical smog and acid rain. $\mathrm{N}_{2} \mathrm{O}$ is estimated to be 296 times more effective as a greenhouse gas than $\mathrm{CO}_{2}$ on a molecular basis (IPCC, 2001). Agricultural soil was primarily responsible for the total global anthropogenic $\mathrm{N}_{2} \mathrm{O}$ emissions, which account for more than a third of all $\mathrm{N}_{2} \mathrm{O}$ emissions (Kroeze et al., 1999; IPCC, 2007). The NO from cultivated lands was

\footnotetext{
* Corresponding authors. Fax: +86 8515891611.

E-mail addresses: pangxb1978@hotmail.com (X. Pang), yjmu@rcees.ac.cn (Y. Mu).
}

estimated to be in a range of $1.6-5.5 \mathrm{Tg} \mathrm{N} \mathrm{yr}^{-1}$, occupied $26-41 \%$ of the global soil source of NO (Yienger and Levy, 1995).

China is a large agricultural country with a cropland area of 157 million ha which account for ca. 7\% of the global total (Chinese Statistical Bureau, 2007). The annual consumed synthetic fertilizer $\mathrm{N}$ contributed ca. $27 \%$ to the global consumption in the mid 1990 s (FAO, 2001). In recent years, many scientists have shown strong interest in the emissions of $\mathrm{NO}_{X}$ and $\mathrm{N}_{2} \mathrm{O}$ from various Chinese croplands including the croplands of rice-wheat rotation (Zheng et al., 2003, 2004; Kreye et al., 2007), maize-wheat rotation (Ding et al., 2007), rice paddies (Cai et al., 1997; Zou et al., 2007), the natural wetlands (Wang et al., 2007), the semi-arid grassland (Zhang and Han, 2008).

However, so far there were few investigations conducted for Chinese vegetable fields (Xiong et al., 2006; Fang and Mu, 2006, 2007; Li and Wang, 2007). In China, vegetable field with a total area of 18.2 million ha, accounts for $11.5 \%$ of the total sown cropland area (Chinese Statistical Bureau, 2007). They are characterized by higher $\mathrm{N}$ application rates than non-vegetable croplands. It had been reported that the $\mathrm{N}$ application rates applied to intensive vegetable fields were averagely up to $1782 \mathrm{~kg} \mathrm{~N} \mathrm{ha}^{-1} \mathrm{yr}^{-1}$ in Shandong province and $1340 \mathrm{~kg} \mathrm{~N} \mathrm{ha}^{-1} \mathrm{yr}^{-1}$ in Jiangsu province (Xiong et al., 
2006), which were more than three-fold the normal rate for nonvegetable crops (Zheng et al., 2004). Therefore, it is necessary to carefully study nitrogenous gases from Chinese vegetable fields to accurately estimate anthropogenic NO emissions.

In this study, $\mathrm{NO}_{\mathrm{X}}$ and $\mathrm{N}_{2} \mathrm{O}$ fluxes from a typical Chinese vegetable field, cultivated with cabbage, garlic and radish, were simultaneously measured in Yangtze River Delta. The seasonal variations of $\mathrm{NO}_{\mathrm{X}}$ and $\mathrm{N}_{2} \mathrm{O}$ fluxes of were studied. The influence of canopy, fertilization, soil temperature, meteorological conditions and tillage on NO emission was carefully investigated and quantified.

\section{Experimental}

\subsection{Experimental site description}

The field experiment was conducted in a vegetable field $\left(30^{\circ} 50^{\prime} \mathrm{N}, 120^{\circ} 42^{\prime} \mathrm{E}\right)$ in Shuangqiao Farm, suburban Jiaxing city, Zhejiang province. The soil is typical of vegetable field soil and its texture is heavy-loam and light-clay. Detailed soil properties can be seen in the previous report (Fang and Mu, 2006). This farm experiences a subtropical monsoon climate, with annual mean rainfall of $1168.6 \mathrm{~mm}$, air temperature of $15.9^{\circ} \mathrm{C}$ and relative humidity of $81 \%$. Monthly mean air temperature is the lowest in January $\left(3.6^{\circ} \mathrm{C}\right)$ and the highest in July $\left(28.1^{\circ} \mathrm{C}\right)$ (http://www.jxqx.net/).

The field with a total area of $16 \times 5 \mathrm{~m}^{2}$ was divided into one $2 \times 5 \mathrm{~m}^{2}$ plot and three $4.5 \times 5 \mathrm{~m}^{2}$ plots by ditches, which were about $20 \mathrm{~cm}$ in width and $20 \mathrm{~cm}$ in depth. The $2 \times 5 \mathrm{~m}^{2}$ plot was an unfertilized plot, which was tilled conventionally but not planted with vegetable, dominated as blank plot. The measurement from blank plot was used to calculate the fertilizer-induced NO emission factors. The other three plots were cultivated as follows: Chinese cabbage (Brassica rapa L. ssp. pekinensis), Garlic (Allium sativum), Radish (Raphanus sativus). Measurement was made in duplicate in blank plot and in triplicate in each of vegetable plots. The background contents of nitrate and ammonium in soil were as $\mathrm{NO}_{3}^{-}-\mathrm{N}$ : 26.6, 22.5, 36.5, and $33.7 \mathrm{mg} \mathrm{kg}^{-1}$, and $\mathrm{NH}_{4}^{+}-\mathrm{N}$ : 22.8, 32, 100, and $65 \mathrm{mg} \mathrm{kg}^{-1}$ for blank, cabbage, garlic and radish plots, respectively.

\subsection{Field management}

At the study site, a local traditional cultivation cycle for vegetables was conducted and mainly included tilling, sowing and basal fertilization, transplanting, topdressing, and second topdressing, respectively. The experimental fields were thoroughly tilled on Aug. 28,2006 . One week later (Sep. 3), radish and cabbage seeds were sowed and the cloves of garlic were cultivated in soil holes. The detailed information about the cultivation and fertilization is listed in Table 1. Complex fertilizer is specially designed for vegetable

Table 1

Cultivation managements and fertilization $\left(\mathrm{kg} \mathrm{N} \mathrm{ha}^{-1}\right)$.

\begin{tabular}{|c|c|c|c|c|c|}
\hline Vegetation & $\begin{array}{l}\text { Growth } \\
\text { period } \\
(\mathrm{mm} / \mathrm{dd} / \mathrm{yy})\end{array}$ & $\begin{array}{l}\text { Transplanting } \\
\text { and tillage } \\
(\mathrm{mm} / \mathrm{dd} / \mathrm{yy})\end{array}$ & $\begin{array}{l}\text { Basal } \\
\text { fertilization } \\
(09 / 03 / 06)\end{array}$ & $\begin{array}{l}\text { Topdressing } \\
(10 / 12 / 06)\end{array}$ & $\begin{array}{l}\text { Second } \\
\text { topdressing } \\
(11 / 02 / 06)\end{array}$ \\
\hline$\overline{\text { Cabbage }}$ & $\begin{array}{l}09 / 03 / 06- \\
12 / 16 / 06 ; \\
\text { (97days) }\end{array}$ & $10 / 09 / 06$ & $\begin{array}{l}\text { Complex } \\
\text { N: } 28.1 ; \\
\text { Manure } \\
\mathrm{N}: 3.4\end{array}$ & $\begin{array}{l}\text { Urea } \\
\text { N: } 201.3\end{array}$ & Urea $\mathrm{N}: 38.4$ \\
\hline Garlic & & $10 / 09 / 06$ & $\begin{array}{l}\text { Complex } \\
\text { N: } 56.3 ; \\
\text { Manure } \\
\text { N: } 3.0\end{array}$ & $\begin{array}{l}\text { Urea } \\
\mathrm{N}: 172.5\end{array}$ & Urea $\mathrm{N}: 35.7$ \\
\hline Radish & & $10 / 09 / 06$ & $\begin{array}{l}\text { Complex N: } \\
66.7 ; \text { Manure } \\
\text { N: } 1.9\end{array}$ & $\begin{array}{l}\text { Urea N: } \\
153.3\end{array}$ & Urea N: 41.7 \\
\hline
\end{tabular}

crops with $\mathrm{N}: \mathrm{P}_{2} \mathrm{O}_{5}: \mathrm{K}_{2} \mathrm{O}=15 \%: 15 \%: 15 \%$. Manure $\mathrm{N}$ denoted dung and urine of human and animals diluted with large amount of water. Urea fertilizer was applied with irrigation.

\subsection{Measurements of $\mathrm{NO}_{X}$ and $\mathrm{N}_{2} \mathrm{O}$ fluxes}

The $\mathrm{NO}_{\mathrm{X}}$ fluxes were measured by a static chamber technique (Fang and Mu, 2006, 2007; Li and Wang, 2007). On each sampling day, $\mathrm{NO}_{\mathrm{X}}$ flux measurement was conducted in the morning (9:0010:00) and afternoon (15:00-16:00). The sampling times were chosen because the $\mathrm{NO}_{\mathrm{X}}$ fluxes at the two periods were found to be approaching to the diurnal average in five diurnal $\mathrm{NO}_{\mathrm{X}}$ measurements (from 7:00 a.m. to7:00 p.m.) in this field campaign. On each sampling occasion, two samples ( $1 \mathrm{~L}$ in volume each) were collected within the duration of $14 \mathrm{~min}$ in Teflon bags from each chamber. $\mathrm{NO}_{\mathrm{X}}$ concentrations were analyzed by an $\mathrm{NO}-\mathrm{NO}_{2}-\mathrm{NO}_{\mathrm{X}}$ analyzer (Thermo Electron model 42i, USA). The fluxes were calculated according to the linear regressions of $\mathrm{NO}_{\mathrm{X}}$ concentrations in chamber versus the time within $20 \mathrm{~min}$. Six values and four values of $\mathrm{NO}_{\mathrm{X}}$ fluxes were obtained from each vegetable plot and the blank plot, respectively, in everyday measurement. The diurnal $\mathrm{NO}_{\mathrm{X}}$ flux displayed in this paper was the mean of the above values and their standard deviations (SD). $\mathrm{N}_{2} \mathrm{O}$ fluxes were usually measured once a week. For each $\mathrm{N}_{2} \mathrm{O}$ flux measurement, two gas samples from each chamber were collected at a 30-min interval. $\mathrm{N}_{2} \mathrm{O}$ was analyzed by a gas chromatography (HP 5890 II) equipped with an ${ }^{63} \mathrm{Ni}$ ECD and three parallel measurements were conducted for every sample.

\subsection{Canopy cutting experiment}

To study the influence of plants canopy on NO flux, the canopy cutting experiments were conducted on two meteorological conditions. On Oct. 13, 2006 with cloudy and calm weather condition, the leaves of vegetables in one of triplicate parallel chambers were quarterly cut and the canopy area decreased linearly to zero. The initial areas of cabbage, garlic, and radish were 5320, 2430, and $3540 \mathrm{~cm}^{2}$, respectively. On Oct. 14, 2006 with sunny and calm weather, the same experimental processes were conducted. The initial areas of cabbage, garlic, and radish in another parallel chamber were 7200,2650 , and $4150 \mathrm{~cm}^{2}$, respectively. The $\mathrm{NO}_{\mathrm{X}}$ concentrations in the chamber after each cutting were measured in triplicate.

\subsection{Determination of environmental variables}

Soil temperature at 5-cm depth and air temperature were measured by mercury thermometer. Every ten-day interval, the composite soil samples were collected from 0 to $5-\mathrm{cm}$ depth to measure their gravimetric soil water contents and mineral $\mathrm{N}$. The mineral $\mathrm{N}\left(\mathrm{NO}_{3}^{-}\right.$and $\left.\mathrm{NH}_{4}^{+}\right)$was extracted by $2 \mathrm{~mol} \mathrm{~L}^{-1} \mathrm{KCl}$ solution and their concentrations were determined through colorimetric analysis. Meteorological parameters including photosynthetically active radiation (PAR), precipitation were measured by a Watchdog Model 900 ET Weather Station (Spectrum Tech., USA) near the field.

\subsection{Statistical analysis}

Six values and four values of $\mathrm{NO}_{\mathrm{X}}$ fluxes were obtained from each vegetable plot and the blank plot, respectively, in everyday measurement. To judge whether there were significant differences among the $\mathrm{NO}_{\mathrm{X}}$ fluxes from the triplicate plots of each vegetable or not, firstly one-sample Kolmogorov-Smirnov test was conducted to analyze those data by SPSS software. The results indicted that 
the test distribution of everyday data was normal. Secondly, the paired-samples $T$-test was used to detect the difference between the morning and afternoon data of $\mathrm{NO}_{\mathrm{X}}$ fluxes from three vegetables plots by SPSS software. It was found that there were no significant differences between morning and afternoon measurements during the whole studying period. Linear correlations were made between $\mathrm{NO}$ and $\mathrm{NO}_{2}$ fluxes from garlic and radish plots after Oct. 12, between $\mathrm{NO}$ emissions and soil mineral $\mathrm{N}$ contents. The Pearson correlation coefficients $(R)$ were displayed in this paper. To affirm which variable is more important in determining NO emission from vegetable fields, multiple linear regression analysis was made among NO emission and fertilizer, soil temperature, gravimetric soil water content by SPSS software.

\section{Results}

\subsection{Temporal variations of NO fluxes}

The time series of NO fluxes from the three vegetable crops and blank field are illustrated as a whole in Fig. 1(a). The average fluxes were $2.87 \pm 2.62,33.8 \pm 44.2,360 \pm 590$ and $76 \pm 112 \mathrm{ngNm}^{-2} \mathrm{~s}^{-1}$ for blank, cabbage, garlic, and radish fields $(n=88)$, respectively, which indicated that the investigated vegetable fields acted as strong sources of atmospheric NO. Over the sampling period, two apparent peaks of NO fluxes occurred following the two topdressing events which were conducted on Oct. 12 and Nov. 2 (Fig. 1(a)). The NO fluxes of garlic plot were significantly higher than those of cabbage and radish plots by one magnitude during most studying period. The peak NO flux of garlic was $2901 \mathrm{ngNm}^{-2} \mathrm{~s}^{-1}$, which was extremely greater than those of cabbage (155 $\mathrm{ngNm}^{-2} \mathrm{~s}^{-1}$ ) and radish $\left(487 \mathrm{ngNm}^{-2} \mathrm{~s}^{-1}\right.$ ), respectively.

What caused the significantly higher NO emission from garlic field was the most interesting thing that we pursued. During the whole field campaign, the $\mathrm{N}$ amount of fertilizers on the garlic field was almost the same or even less than that on cabbage and radish fields (Table 1). Thus, the $\mathrm{N}$ amount of fertilizers may not be the direct reason for the higher NO fluxes of garlic plot. A higher background soil inorganic $\mathrm{N}$ content $\left(\mathrm{NH}_{4}^{-}-\mathrm{N}\right.$ and $\left.\mathrm{NO}_{3}^{-}-\mathrm{N}\right)$ was found in garlic plot (Fig. 2), which could provide more $\mathrm{N}$ nutrient elements for nitrification or denitrification occurring in soil and resulted in a larger NO emission.

Furthermore, the diversity of vegetables canopy may be one important reason causing the great gap in the NO fluxes. As Fig. 1(a) shows, there are no significant differences among the NO fluxes when the plants were all at the germinant stage with little canopy (before Sep. 20). However, during the whole Oct. and early Nov., considerably higher NO fluxes in garlic plot were observed possibly because the canopies of garlic were extremely smaller than those of cabbage and radish in the flourishing stage. To further study the influence of vegetable canopy on NO emission, canopy-cutting experiment was conducted. On a cloudy day (Oct. 13, 2006), the leaves of vegetables in one parallel chamber were cut step by step and the canopy area decreased linearly. It was found that NO fluxes increased proportionally with the canopies reductions (Fig. 3). On a sunny day (Oct. 14, 2006), the effect of canopy was studied again and $\mathrm{NO}_{\mathrm{X}}$ fluxes were found to increase in a nonlinear mode. Higher increasing extent was found in the initial canopies reduction, while the increasing intensity became less gradually with the further canopies reduction (Fig. 3).

It should be noted that the NO flux of radish plot was also greatly higher than that of cabbage plot almost during the whole measuring period. The higher NO flux of radish plot might be ascribed to the higher soil temperature of radish plot than that of cabbage plot with an increment of $1-3{ }^{\circ} \mathrm{C}$ (Fig. 4).

\subsection{Temporal variations of $\mathrm{NO}_{2}$ fluxes}

As Fig. 1(b) shows, the blank and cabbage plots acted as the sinks for atmospheric $\mathrm{NO}_{2}$ during most time of the studying period, while the garlic and radish plots acted as the sources. The average fluxes were $-2.5,-1.03,0.76$, and $0.93 \mathrm{ngNm}^{-2} \mathrm{~s}^{-1}(n=88)$ for blank, cabbage, garlic and radish fields, respectively. Before Oct.11, $\mathrm{NO}_{2}$ emissions from all plots were close to zero. Apparent $\mathrm{NO}_{2}$ emissions of garlic and radish plots were observed during two measuring periods (Oct. 12-Nov. 2 and Nov.14-Dec.10), which coincided with the periods of peak NO emission of garlic and radish plots. Correlation analysis was conducted between $\mathrm{NO}$ and $\mathrm{NO}_{2}$ emissions during the two periods and the correlation coefficients $\left(R^{2}\right)$ were found to be high to 0.668 , and $0.594(n=32)$ for garlic and radish plots, respectively. The phenomenon indicated that the $\mathrm{NO}_{2}$ emission had a close correlation with the NO emission.

\section{3. $\mathrm{N}_{2} \mathrm{O}$ fluxes from vegetable fields}

Temporal variations of $\mathrm{N}_{2} \mathrm{O}$ fluxes of three vegetable fields are illustrated in Fig. 1(c) and they show exactly similarly tendencies. The $\mathrm{N}_{2} \mathrm{O}$ fluxes of cabbage, garlic and radish fields varied in the ranges of $0.6-38.5,0.9-104.5$, and $0.2-16.8 \mathrm{ngN} \mathrm{m}^{-2} \mathrm{~s}^{-1}$ with the averages of $5.8,8.8$, and $4.3 \mathrm{ngN} \mathrm{m}^{-2} \mathrm{~s}^{-1}(n=29)$, respectively. It is obviously shown that $\mathrm{N}_{2} \mathrm{O}$ emission occurred in pulses, not continuously throughout the growing period in Fig. 1(c). Similar pulse pattern of $\mathrm{N}_{2} \mathrm{O}$ emission was observed in the vegetable fields of Nanjing city, China (Xiong et al., 2006). The $\mathrm{N}_{2} \mathrm{O}$ emission peaks appeared on Oct. 10 just after radish and cabbage were transplanted and their fields were subsequently tilled on Oct. 9. Slight increases of $\mathrm{N}_{2} \mathrm{O}$ fluxes were found on Oct. 25. During the other growing period, $\mathrm{N}_{2} \mathrm{O}$ fluxes were low and relatively stable between 1 and

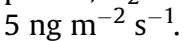

\subsection{Variations of soil prosperities and meteorological conditions}

Soil mineral $\mathrm{N}\left(\mathrm{NO}_{3}^{-}\right.$and $\left.\mathrm{NH}_{4}^{+}\right)$contents had similar varying tendencies in three vegetable fields. Soil $\mathrm{NH}_{4}^{+}$contents were maximum on 8 Nov., which was coincident with the time of peak NO emissions (Fig. 2). The highest mineral N contents were found in garlic cropland, followed by radish and cabbage croplands. The gravimetric soil water contents of the field varied in the ranges of $11-34 \%$ (with a mean of $21.7,19.8$ and $20.6 \%$ for cabbage, garlic and radish fields, respectively) and high soil water contents were found in the samples collected after wet precipitation (Fig. 4). Soil temperatures varied in the ranges of 7.0-30.1, 8.2-30.9 and 7.5$30.6^{\circ} \mathrm{C}$ for cabbage, garlic and radish plots, respectively (Fig. 4). In most time, the soil temperature of garlic field was the maximum, followed by radish and cabbage plots.

\section{Discussion}

\subsection{Influencing factors on $\mathrm{NO}_{X}$ and $\mathrm{N}_{2} \mathrm{O}$ emissions}

$\mathrm{NO}_{\mathrm{X}}$ and $\mathrm{N}_{2} \mathrm{O}$ fluxes from agricultural soils were strongly affected by many factors, including fertilization application, soil properties, canopy density, cultivation, and weather conditions, etc. (Williams et al., 1992). The application of $\mathrm{N}$ fertilizers can significantly promote NO emission because the increased soil mineral $\mathrm{N}$ will stimulate bacteria to nitrify or denitrify to produce NO more quickly (Bouwman et al., 2002; Ludwig et al., 2001). This may be the reason why two peaks of NO fluxes occurred after the two topdressing events on Oct. 12 and Nov. 2. Since most of the $\mathrm{NO}_{\mathrm{X}}$ produced by soil was NO and there was no evidence for biological production of $\mathrm{NO}_{2}$ in soil (Williams et al., 1992), the high levels of 


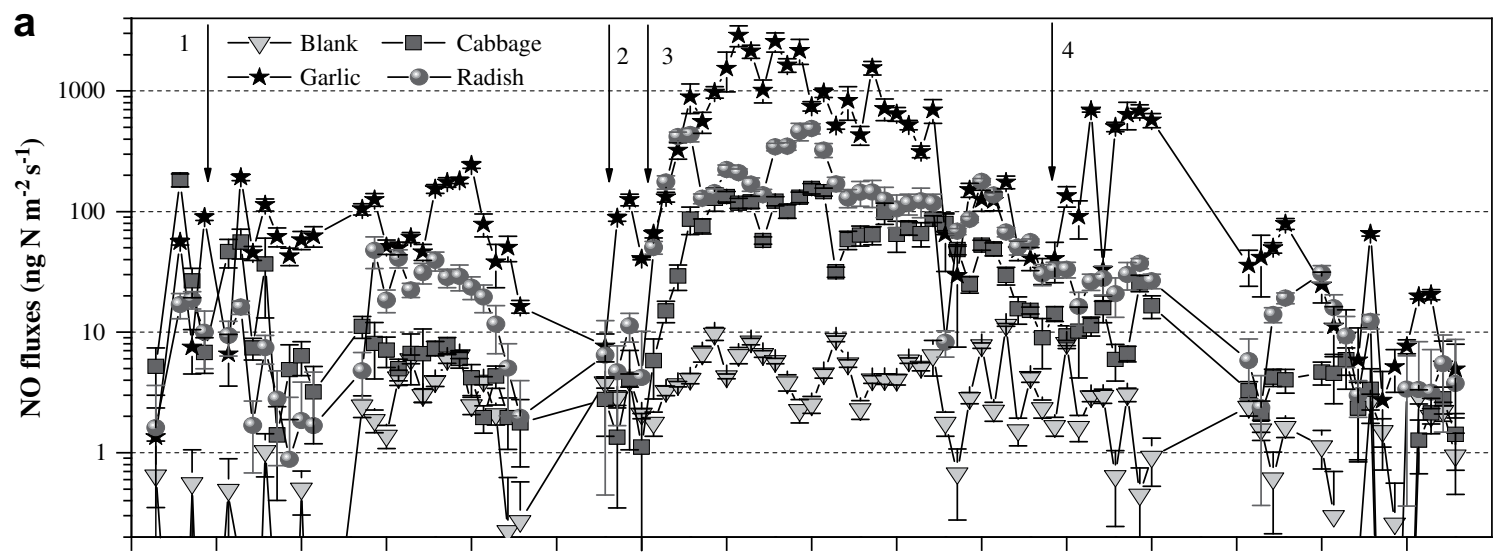

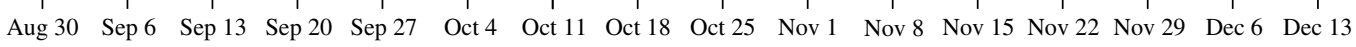

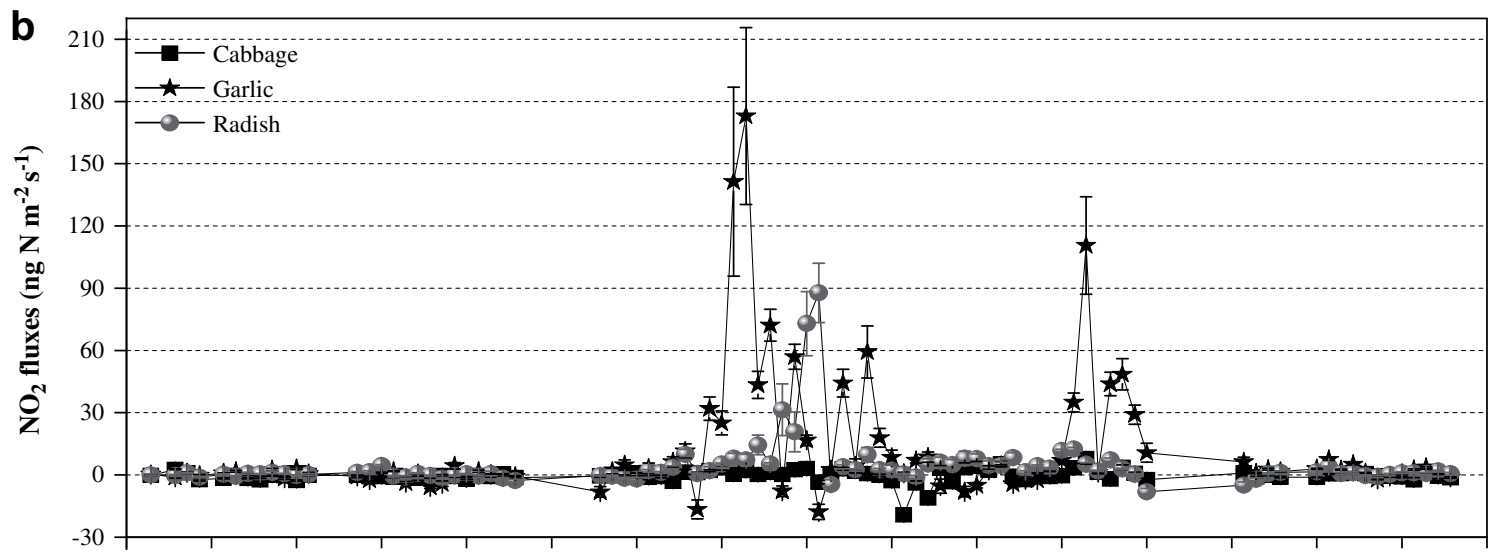

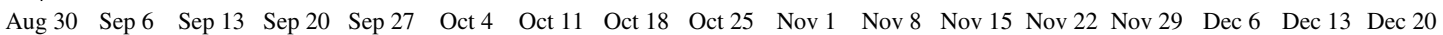

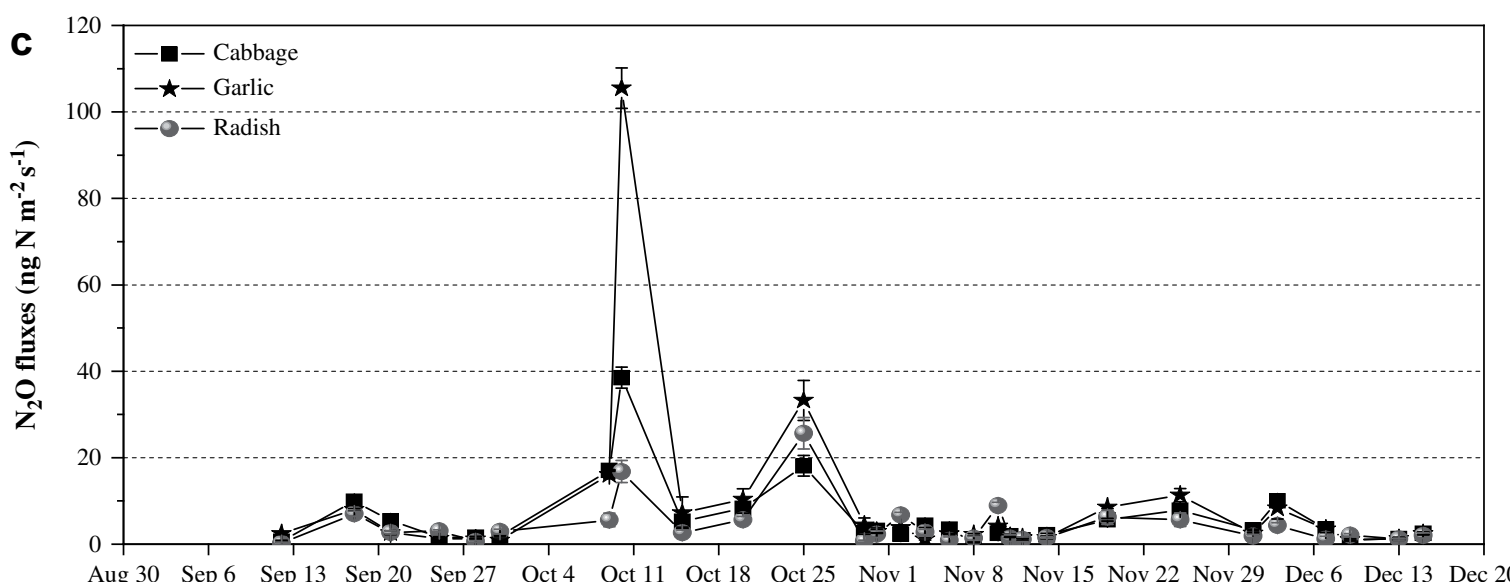

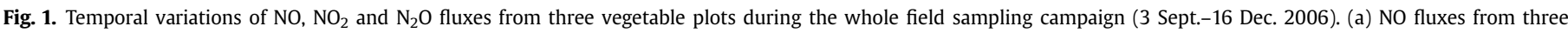

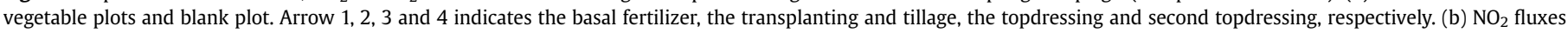
from three vegetables plots. (c) $\mathrm{N}_{2} \mathrm{O}$ fluxes from three vegetables plots. Error bars in this figure indicate the standard deviations (SD).

NO accumulated in the chambers could be easily oxidized to $\mathrm{NO}_{2}$ by atmospheric $\mathrm{O}_{3}$ (Walton et al., 1997). This may be the reason why the high $\mathrm{NO}_{2}$ fluxes from the garlic and radish plots during the periods of peak NO emission (Oct.12-Nov. 2 and Nov.14-Dec.10). In this study, soil $\mathrm{NH}_{4}^{+}$content was found to have a good correlation with NO fluxes $\left(R^{2}=0.81,0.73\right.$ and 0.69 for cabbage, garlic and radish, respectively, $n=16$ ). This phenomenon indicated that the nitrification was the dominant process to produce NO in soil (Akiyama and Tsuruta, 2003). Fertilizer input can also increase the soil $\mathrm{N}_{2} \mathrm{O}$ emission (Bouwman, 1990). Slight increase of $\mathrm{N}_{2} \mathrm{O}$ fluxes on Oct. 25 may be ascribed to the intensive fertilization on Oct. 19. Additionally, tillage could cause immediate changes in microbial community structure of soil and produce large $\mathrm{N}_{2} \mathrm{O}$ emission (Xiong et al., 2006), which caused the peak $\mathrm{N}_{2} \mathrm{O}$ emission on Oct. 10 in this study.

Soil temperature and gravimetric soil water content are also the dominant factors in NO fluxes. In this study, the soil temperature was found to have an exponential relationship with NO flux in most of the measurements after Oct.12. The equations between NO flux and soil temperature were Flux $_{\mathrm{NO}}=19.3 \exp (0.08 T)-37.6$ 


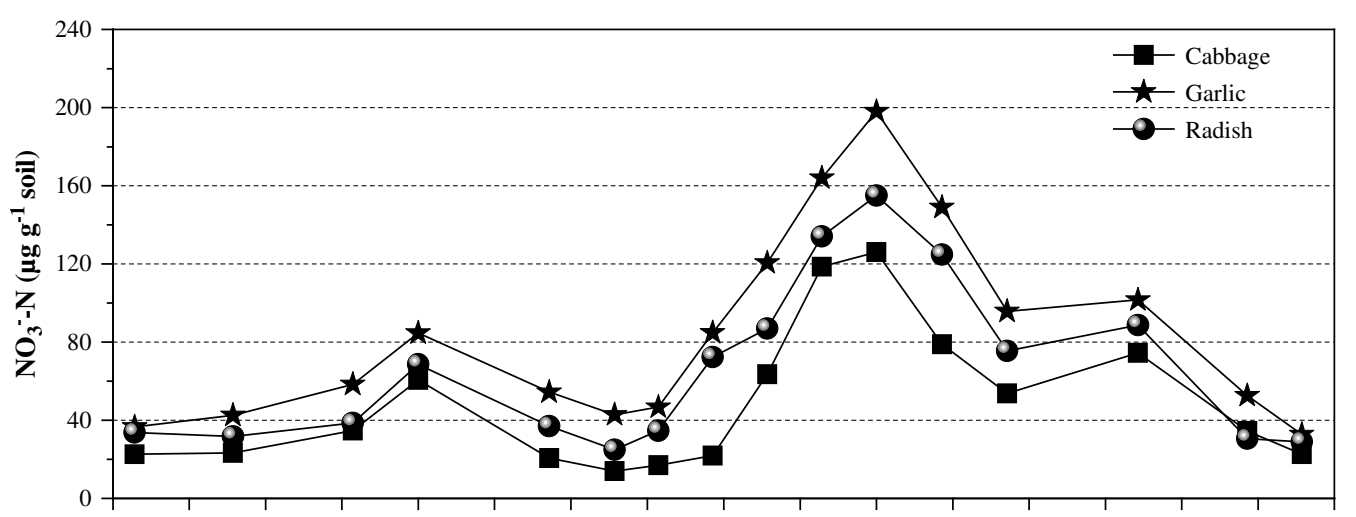

Aug 30 Sep 6 Sep 13 Sep 20 Sep 27 Oct 4 Oct 11 Oct 18 Oct 25 Nov 1 Nov 8 Nov 15 Nov 22 Nov 29 Dec 6 Dec 13 Dec 20

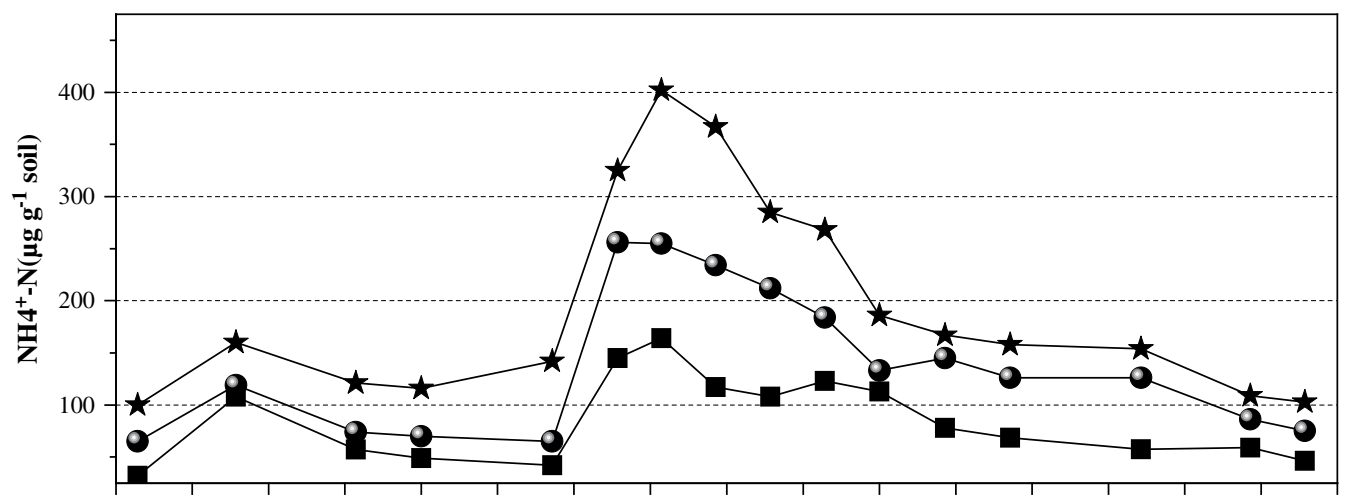

Aug 30 Sep 6 Sep 13 Sep 20 Sep 27 Oct 4 Oct 11 Oct 18 Oct 25 Nov 1 Nov 8 Nov 15 Nov 22 Nov 29 Dec 6 Dec 13 Dec 20

Fig. 2. Soil mineral $\mathrm{N}\left(\mathrm{NO}_{3}^{-}\right.$and $\left.\mathrm{NH}_{4}^{+}\right)$contents in three vegetable fields during the whole field sampling period.

$\left(R^{2}=0.81\right)$, Flux $_{\mathrm{NO}}=5.5 \exp (0.23 T)-33\left(R^{2}=0.81\right)$ and Flux $_{\mathrm{NO}}=69.6 \exp (0.07 T)-13.5\left(R^{2}=0.61\right)$ for cabbage, garlic and radish plots, respectively. The exponential relationship might be attributed to the reason that microbial activity in soil will rise exponentially with soil temperature as NO production is mainly from microbial mediated nitrification and denitrification (Williams et al., 1992; Fang et al., 2006). NO fluxes usually decreased in the condition of the high gravimetric soil water contents after wet precipitation such as the fluxes of Sep. 10, Sep.27, Nov. 20 and Dec. 12 (Fig. 1(a)). The soil pore spaces filled with water would inhibit NO gas from transporting (Akiyama et al., 2004). In addition, wet precipitation can lower surface soil temperature, wash $\mathrm{N}$ fertilizer to deep soil, and change the structure of microbial community (Jackson et al., 2003).
To estimate which variable plays more important role in influencing NO flux, a multiple linear regression analysis was made among NO flux and fertilizer amount $(F)$, natural exponential functions of soil temperature $(\operatorname{Exp}(m T), m$ is a coefficient. It is 0.07 for cabbage, 0.23 for garlic and 0.08 for radish according to the above equations between soil temperature and NO flux), gravimetric soil water content $(W)$. The relative coefficients $(R)$ and significances $(p)$ of linear equations in Table 2 indicate that NO fluxes had a perfect linear regression relationship with the three factors. According to the values of the significances $(p)$ of three variables and NO flux, the natural exponent of soil temperature was found to be the most predominant factor in controlling NO fluxes from three vegetables plots, followed by soil water content and soil temperature (Table 2). Fertilizer amount and soil temperature had

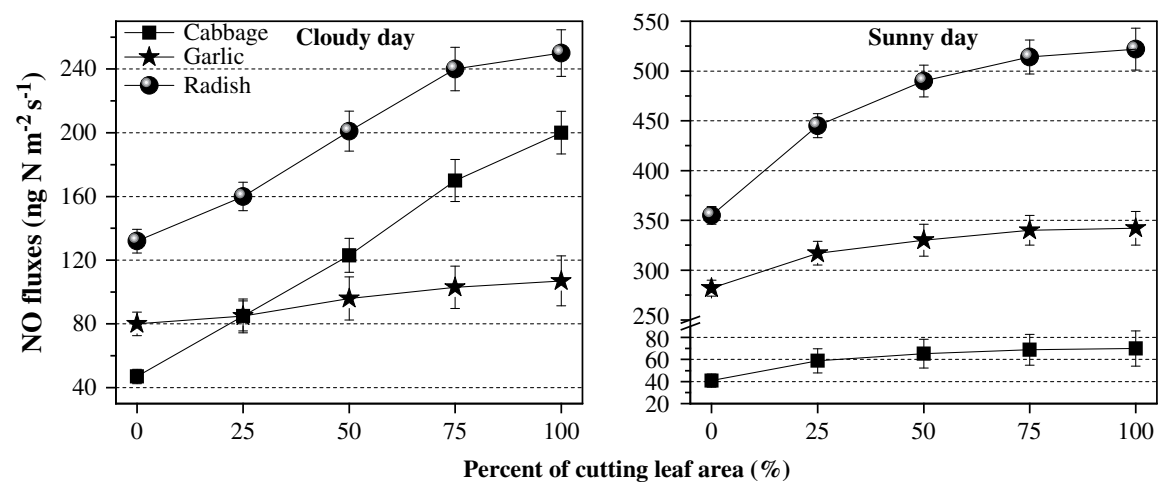

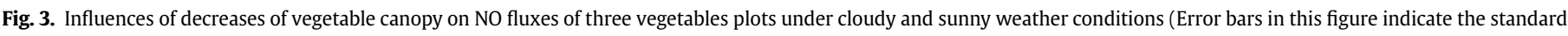
deviations (SD)). 

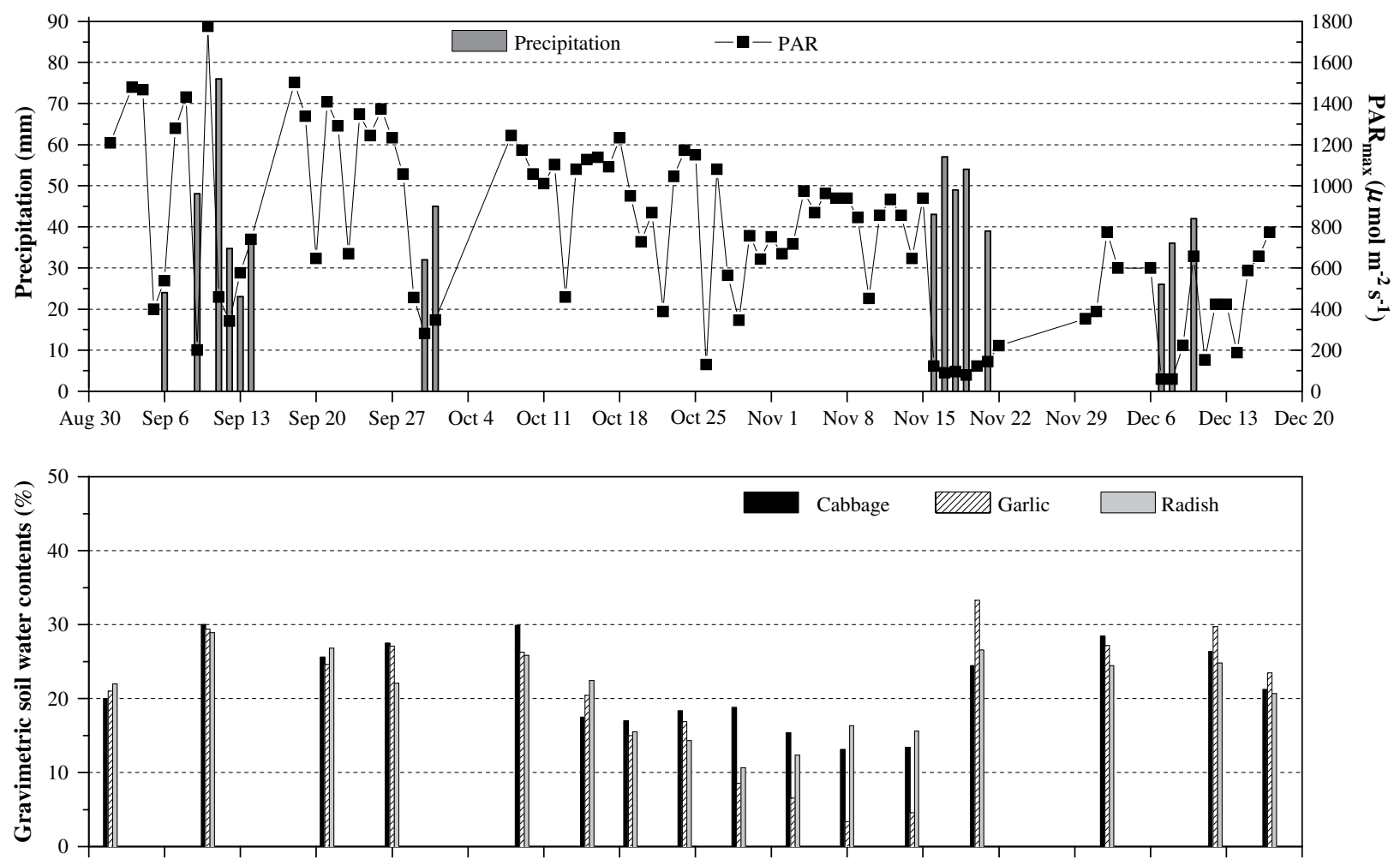

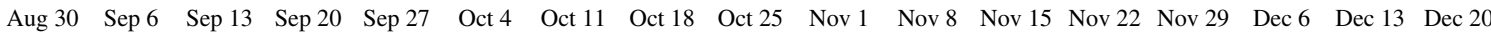

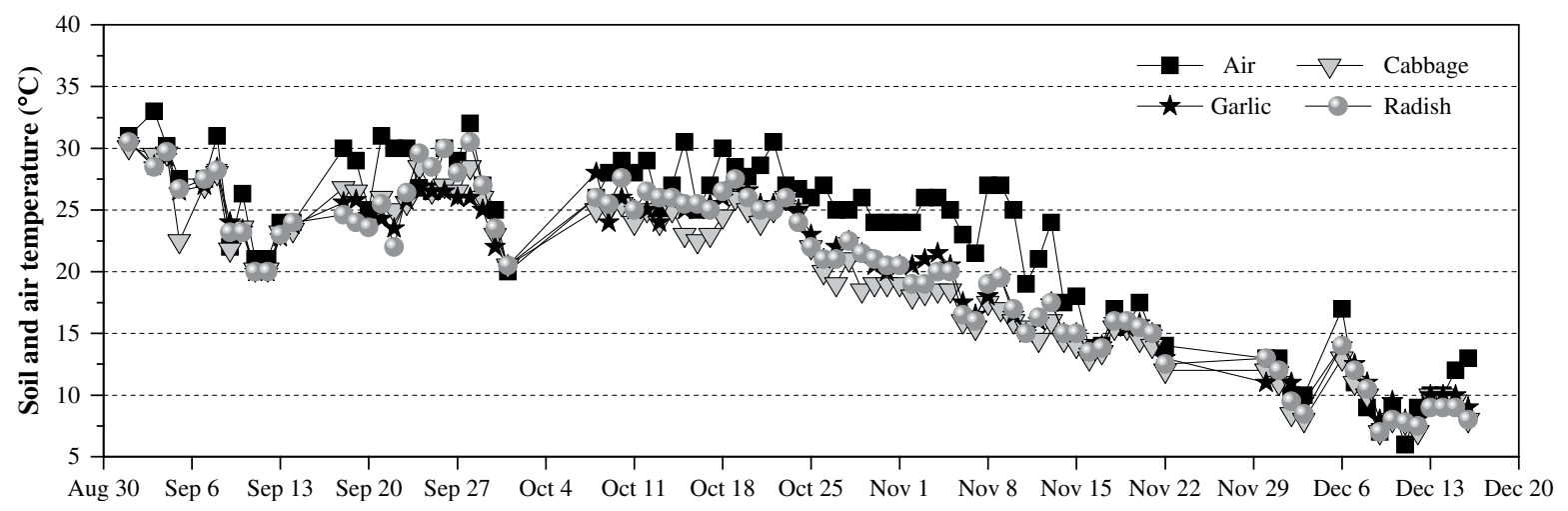

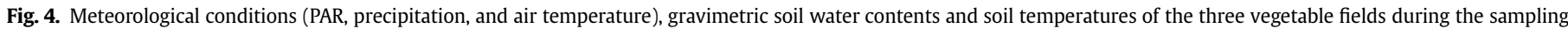
period.

Table 2

Regression equations between NO flux and its factors fertilizer amount, soil temperature, and gravimetric soil water contents in vegetables fields.

\begin{tabular}{|c|c|c|c|c|c|c|}
\hline \multirow[t]{2}{*}{ Factor } & \multicolumn{2}{|c|}{ Cabbage } & \multicolumn{2}{|c|}{ Garlic } & \multicolumn{2}{|c|}{ Radish } \\
\hline & $\overline{\mathrm{B}^{\mathrm{d}}}$ & $p^{\mathrm{e}}$ & $\bar{B}$ & $p$ & $\bar{B}$ & $P$ \\
\hline$\overline{\operatorname{Exp}(m T)^{\mathrm{b}}}$ & 24.8 & 0.020 & 2.92 & 0.041 & 72.9 & 0.043 \\
\hline$F^{\mathrm{a}}$ & 0.114 & 0.579 & 6.23 & 0.141 & 1.45 & 0.659 \\
\hline$W^{c}$ & -0.43 & 0.730 & 15.5 & 0.184 & -7.43 & 0.544 \\
\hline Equation & \multicolumn{2}{|c|}{$\begin{array}{l}\mathrm{NO}=0.114 \mathrm{~F}+ \\
24.8 \operatorname{Exp}(0.07 \mathrm{~T})- \\
0.43 \mathrm{~W}-36 \\
(R=0.977 \\
p<0.001)\end{array}$} & \multicolumn{2}{|c|}{$\begin{array}{l}\mathrm{NO}=6.23 F+ \\
2.92 \operatorname{Exp}(0.23) T \\
+15.5 W-574 \\
(R=0.955 \\
p<0.001)\end{array}$} & \multicolumn{2}{|c|}{$\begin{array}{l}\mathrm{NO}=1.45 F+ \\
72.9 \operatorname{Exp}(0.08) T- \\
7.43 W+42.4 \\
(R=0.923 \\
p=0.003)\end{array}$} \\
\hline
\end{tabular}

a Natural exponential functions of soil temperature: $m$ is a coefficient. It is 0.07 for cabbage, 0.23 for garlic and 0.08 for radish.

b Fertilizer amount.

c Gravimetric soil water contents.

d Unstandardized coefficients.

e Significance. a positive relation with NO emissions while soil water content had negative effect on NO emissions in cabbage and radish plots.

Many evidences suggested that the vegetable canopy had a shielding influence on the air/soil exchange of NO and could significantly prevent soil-emitted NO from escaping into the ambient atmosphere (Lovett and Lindberg, 1993; Hereid and Monson, 2001; Fang and $\mathrm{Mu}, 2006$ ). The varying patterns of $\mathrm{NO}_{\mathrm{X}}$ fluxes with the decreases of canopy density in this study (Fig. 3) may be ascribed to the different stomatal conductance of leaves under different weather conditions. It had been well documented that stomata conductance controlled the diffusion of $\mathrm{NO}_{\mathrm{X}}$ into plant leaves and it increased with the increasing PAR (Hereid and Monson, 2001; Sparks et al., 2001). On cloudy weather condition, the airstomatal of leaves usually close down and the stomata conductance is the minimum. As a result, the diffusive process between $\mathrm{NO}$ and the intercellular air spaces of leaves wound be blocked (Hereid and Monson, 2001). In this case, the vegetable canopy could simply 
Table 3

$\mathrm{NO}$ and $\mathrm{N}_{2} \mathrm{O}$ fluxes $\left(\mathrm{ngNm}^{-2} \mathrm{~s}^{-1}\right)$, fertilizer $\mathrm{N}$ rates $\left(\mathrm{kg} \mathrm{N} \mathrm{ha}^{-1}\right)$ and cumulate emission rates $\left(\mathrm{kg} \mathrm{N}^{-1}\right)$ from fertilized vegetable fields in China.

\begin{tabular}{|c|c|c|c|c|c|c|c|c|c|}
\hline Location & Time & Vegetables & Fertilizer type & Fertilizer $\mathrm{N}$ rates & NO flux & $\mathrm{N}_{2} \mathrm{O}$ flux & Cumulate NO & Cumulate $\mathrm{N}_{2} \mathrm{O}$ & $\mathrm{N}$ loss $(\%)$ \\
\hline \multirow[t]{4}{*}{$\overline{\text { Nanjing }^{\mathrm{a}}}$} & \multirow[t]{4}{*}{ Nov. 2001-Jan. 2003} & Radish & $\mathrm{CF}+$ urea & 323 & $--^{j}$ & $10.3 \pm 2.8$ & - & $1.3 \pm 0.4$ & 0.39 \\
\hline & & Baby bok choy & $\mathrm{CF}+$ urea & 142 & - & $35.8 \pm 7.8$ & - & $1.0 \pm 0.2$ & 0.72 \\
\hline & & Lettuce & $\mathrm{CF}+\mathrm{M}$ & 129 & - & $71.1 \pm 5.0$ & - & $2.9 \pm 0.2$ & 2.24 \\
\hline & & Celery & Urea $+M$ & 796 & - & $83.3 \pm 1.4$ & - & $5.8 \pm 0.1$ & 0.73 \\
\hline \multirow[t]{2}{*}{ Yangtze Delta ${ }^{\mathrm{b}}$} & \multirow[t]{2}{*}{ Mar.-May 2005} & Cabbage & $\mathrm{CF}$ & 45 & 11.5 & - & 0.27 & - & 0.6 \\
\hline & & Potato & $\mathrm{CF}+\mathrm{M}$ & 45.6 & 34.2 & - & 1.64 & - & 3.6 \\
\hline \multirow[t]{3}{*}{ Yangtze Delta ${ }^{c}$} & \multirow[t]{3}{*}{ Mar.-June 2006} & cabbage & $\mathrm{CF}$ & 135 & 20.9 & - & 1.42 & - & 1.05 \\
\hline & & Potato & $\mathrm{CF}+\mathrm{M}$ & 108 & 27.4 & - & 1.89 & - & 1.75 \\
\hline & & Soybean & $\mathrm{CF}+$ urea & 81 & 21.4 & - & 1.48 & - & 1.83 \\
\hline \multirow[t]{3}{*}{ Yangtze Delta $^{\mathrm{d}}$} & \multirow[t]{3}{*}{ Sep.-Dec. 2006} & Cabbage & $\mathrm{CF}+\mathrm{M}+$ urea & 271.2 & 33.8 & 5.78 & 2.83 & 0.48 & 1.2 \\
\hline & & Garlic & $\mathrm{CF}+\mathrm{M}+$ urea & 267.3 & 360 & 8.76 & 30.2 & 0.73 & 11.56 \\
\hline & & Radish & $\mathrm{CF}+\mathrm{M}+$ urea & 263.6 & 76.0 & 4.32 & 6.4 & 0.36 & 2.56 \\
\hline Pearl River Delta ${ }^{\mathrm{e}}$ & Sep.-Oct.05 & Cabbage & $\mathrm{CF}+\mathrm{M}+$ urea & 63.5 & 47.5 & - & 2.05 & - & 2.4 \\
\hline \multirow[t]{2}{*}{ Inner Mongolia ${ }^{f}$} & \multirow[t]{2}{*}{ Apr.-Oct. } & Grass & Urea & 100 & - & - & - & 1.068 & 0.358 \\
\hline & & Cropland & Urea & 100 & & - & & 1.266 & 0.526 \\
\hline Henan Province ${ }^{g}$ & June 2004-June 2005 & Maize wheat & Urea & 150 & & & & 2.46 & 0.61 \\
\hline Yangtze Delta $^{\mathrm{h}}$ & Nov.-May & Rice-wheat & Urea & 191 & 72 & & 3.89 & & 2.04 \\
\hline \multirow[t]{2}{*}{ Nanjing ${ }^{\mathrm{i}}$} & \multirow[t]{2}{*}{ May-Sep. } & Rice & Urea & 300 & - & 6.4 & - & 0.62 & 0.21 \\
\hline & & Rice & $\left(\mathrm{NH}_{4}\right)_{2} \mathrm{SO}_{4}$ & 300 & - & 10.1 & - & 0.98 & 0.33 \\
\hline
\end{tabular}

a Xiong et al. (2006)

b Fang and Mu (2006).

c Fang and Mu (2007).

d This study.

e Li and Wang (2007).

${ }^{f}$ Zhang and Han (2008)

g Ding et al. (2007).

h Zheng et al. (2003)

i Cai et al. (1997).

$\mathrm{j}$ Indicates that the value was not determined.

mitigate soil-NO emission as a shield, which may be responsible for the linear correlation between NO flux and canopy reduction. At noon of a sunny day, stomatal conductance of canopy is the highest and the diffusion of NO into plant leaves is likely to be the most active. Under this circumstance, the vegetable canopy cannot only prevent soil-NO emission but also significantly assimilate NO. This may be the reason for why $\mathrm{NO}_{\mathrm{X}}$ fluxes increased in a nonlinear mode with the canopy reduction on the sunny day (Fig. 3).

\subsection{Comparisons of $\mathrm{NO}$ and $\mathrm{N}_{2} \mathrm{O}$ emissions from various croplands}

$\mathrm{NO}_{\mathrm{X}}$ and $\mathrm{N}_{2} \mathrm{O}$ emissions from various croplands in China are listed in Table 3. The NO flux from the same cabbage field increased from 11.5(Fang and Mu, 2006), 20.9(Fang and Mu, 2007), to $33.8 \mathrm{ngNm}^{-2} \mathrm{~s}^{-1}$ as the amount of $\mathrm{N}$ fertilization used increased from 45, 135-271.2 $\mathrm{kgN} \mathrm{ha}^{-1}$. In Pearl River Delta (Li and Wang, 2007), the NO flux from cabbage field ( $47.5 \mathrm{ngNm}^{-2} \mathrm{~s}^{-1}$ ) was higher than that in this study in spite of the lower amount of $\mathrm{N}$ fertilization $\left(63.5 \mathrm{kgN} \mathrm{ha}^{-1}\right)$. This may be ascribed to different types of climates and soils between two studying sites. Compared with the vegetable fields in Yangtze River Delta, the rice-wheat rotation cropland had a significantly higher NO flux (Zheng et al., 2003).

It should be noted that the $\mathrm{N}_{2} \mathrm{O}$ fluxes in this study were extremely lower than those from the vegetables field in Nanjing (Xiong et al., 2006), in spite of more $\mathrm{N}$ fertilizer used in this study. This phenomenon implies that $\mathrm{N}_{2} \mathrm{O}$ fluxes are associated not only with the amount of fertilizer but also with the soil properties, weather conditions, agronomic practices and growing periods. The $\mathrm{N}_{2} \mathrm{O}$ emission may have been underestimated due to low frequent sampling in our measurement because $\mathrm{N}_{2} \mathrm{O}$ emission events usually occur in pulses (Xiong et al., 2006) and some high fluxes may be ignored by low frequent sampling. The $\mathrm{N}_{2} \mathrm{O}$ fluxes in this study were found to be comparable to those from the rice fields in
Nanjing with the similar amount of nitrogen fertilizer (Cai et al., 1997). From the results in Table 3 , the averages of NO flux (360 $\mathrm{ngN} \mathrm{m}^{-2} \mathrm{~s}^{-1}$ ) and nitrogen loss factor (11.56\%) of garlic field in this study were found to be the maximum.

As the vegetable croplands in China were characterized by intensive fertilization and cultivation, the NO emission may be an important source of national NO emission. Therefore, it is necessary to reduce NO emission from vegetable cropland by scientifically using fertilizer, especially for garlic field.

\section{Conclusion}

Measurement of $\mathrm{NO}_{\mathrm{X}}$ and $\mathrm{N}_{2} \mathrm{O}$ emissions from typical vegetable cropland in Yangtze River Delta indicated that vegetable cropland was an important source of $\mathrm{NO}$ and $\mathrm{N}_{2} \mathrm{O}$ emissions. Influence of vegetables canopy on NO emission was studied, which indicated that on cloudy days canopy could only shield NO emitting but on sunny days it could not only prevent NO emissions but also assimilate NO through the open leaves stomas. High soil temperature and great fertilizer amount can promote NO emissions while high soil water content will restrain NO emissions in cabbage and radish plots. Since $\mathrm{N}_{2} \mathrm{O}$ fluxes from the vegetable fields occur in pulses, higher frequent $\mathrm{N}_{2} \mathrm{O}$ measurements are needed for further study to avoid underestimating the $\mathrm{N}_{2} \mathrm{O}$ emission. About $1.2 \%$, $11.56 \%$ and $2.56 \%$ of applied fertilizer $\mathrm{N}$ was emitted as NO-N and $\mathrm{N}_{2} \mathrm{O}-\mathrm{N}$ from the cabbage, garlic, and radish fields respectively during studying period. By scientifically using fertilizer, it is hopeful to reduce NO emission from vegetable cropland.

\section{Acknowledgements}

This research has received the financial support of the Chinese National Natural Science Foundation (20807041, 40872212, 40830101, 
20677067), the National Basic Research Program of China (2005CB422201, 2005CB422206), China Postdoctoral Science Foundation (200801270, 20080430861) Innovation Program of Chinese Academy of Sciences (KZCX2-YW-Q02-03), and Municipal Science and Technology Foundation of Guizhou Province (2008GZ02725).

\section{References}

Akiyama, H., McTaggart, I., Ball, B.C., Scott, A., 2004. $\mathrm{N}_{2} \mathrm{O}$, $\mathrm{NO}$ and $\mathrm{NH}_{3}$ emissions from soil after the application of organic fertilizers, urea and water. Water, Air, and Soil Pollution 156, 113-129.

Akiyama, H., Tsuruta, H., 2003. Effect of organic matter application on $\mathrm{N}_{2} \mathrm{O}$, NO, and $\mathrm{NO}_{2}$ fluxes from an Andisol field. Global Biogeochemical Cycles 17, 1100. doi:10.1029/2002GB002016.

Bouwman, A.F., 1990. Exchange of greenhouse gases between terrestrial ecosystems and the atmosphere. In: Bouwman, A.F. (Ed.), Soils and the Greenhouse Effect. John Wiley, Chichester, pp. 61-127.

Bouwman, A.F., Boumans, L.J.M., Batjes, N.H., 2002. Modeling global annual $\mathrm{N}_{2} \mathrm{O}$ and NO emissions from fertilized fields. Global Biogeochemical Cycles 16, 1080. doi:10.1029/2001GB001812.

Cai, Z.C., Xing, G.X., Yan, X.Y., Xu, H., Tsuruta, H., Yagi, K., Minami, K., 1997. Methane and nitrous oxide emissions from rice paddy fields as affected by nitrogen fertilisers and water management. Plant and Soil 196, 7-14.

Chinese Statistical Bureau, 2007. China Statistical Yearbook. Chinese Statistical Bureau, Beijing, China.

Ding, W., Cai, Y., Cai, Z., Yagi, K., Zheng, X., 2007. Nitrous oxide emissions from an intensively cultivated maize-wheat rotation soil in the North China Plain. Science of the Total Environment 373, 501-511.

Dong, H., Zhu, Z., Shang, B., Kang, G., Zhu, H., Xin, H., 2007. Greenhouse gas emissions from swine barns of various production stages in suburban Beijing, China. Atmospheric Environment 41, 2391-2399.

Fang, S., Zhang, Y., Mu, Y., 2006. Surface-exchange of $\mathrm{NO}_{\mathrm{X}}$ and $\mathrm{NH}_{3}$ above a winter wheat field in the Yangtze Delta, China. Journal of Environmental Sciences 18 (4), 689-700.

Fang, S., Mu, Y., 2006. Air/surface exchange of nitric oxide between two typical vegetable lands and the atmosphere in the Yangtze Delta, China. Atmospheric Environment 40, 6329-6337.

Fang, S., Mu, Y., 2007. NOx fluxes from three kinds of agricultural lands in the Yangtze Delta, China. Atmospheric Environment 41, 4766-4772.

FAO, 2001. Food and Agricultural Organization Statistical Database. http://apps.fao.org.

Hereid, D.P., Monson, R.K., 2001. Nitrogen oxide fluxes between corn (Zea mays L.) leaves and the atmosphere. Atmospheric Environment 35, 975-983.

IPCC, 2001. In: Houghton, J.T., Ding, Y., Griggs, D.J., Noguer, M., van der Linden, P.J., Xiaosu, D. (Eds.), Climate Change 2001: The Scientific Basis. Contribution of Working Group I to the Third Assessment Report of the Intergovernmental Panel on Climate Change. Cambridge University Press, Cambridge.

IPCC, 2007. IPCC WGI Fourth Assessment report, summary for policymakers.
Jackson, L.E., Calderon, F.J., Steenwerth, K.L., Scow, K.M., Rolston, D.E., 2003. Responses of soil microbial processes and community structure to tillage events and implications for soil quality. Geoderma 114 (3-4), 305-317.

Kreye, C., Dittert, K., Zheng, X.H., Zhang, X., Lin, S., Tao, H.B., Sattelmacher, B., 2007. Fluxes of methane and nitrous oxide in water-saving rice production in North China. Nutrient Cycling in Agroecosystems 77, 293-304.

Kroeze, C., Mosier, A., Bouwman, L., 1999. Closing the $\mathrm{N}_{2} \mathrm{O}$ budget: a retrospective analysis 1500-1994. Global Biochemistry Cycles 13, 1-8.

Li, D., Wang, X., 2007. Nitric oxide emission from a typical vegetable field in the Pearl River Delta, China. Atmospheric Environment 41, 9498-9505.

Lovett, G.M., Lindberg, S.E., 1993. Atmospheric deposition and canopy interactions of nitrogen in forest. Canadian Journal of Forest Research 23, 1603-1616.

Ludwig, J., Meixner, F.X., Vogel, B., Forstner, J., 2001. Soil-air exchange of nitric oxide: an overview of processes, environmental factors, and modeling studies. Biogeochemistry 52, 225-257.

Sparks, J.P., Monson, R.K., Sparks, K.L., Lerdau, M., 2001. Leaf uptake of nitrogen dioxide $\left(\mathrm{NO}_{2}\right)$ in a tropical wet forest: implications for tropospheric chemistry. Oecologia 127, 214-221.

Walton, S., Gallagher, M.W., Duyzer, J.H., 1997. Use of a detailed model to study the exchange of $\mathrm{NO}_{\mathrm{X}}$ and $\mathrm{O}_{3}$ above and below a deciduous canopy. Atmospheric Environment 31, 2915-2931.

Wang, H.J., Yang, L.Y., Wang, W.D., Lu, J.W., Yin, C.Q., 2007. Nitrous oxide $\left(\mathrm{N}_{2} \mathrm{O}\right)$ fluxes and their relationships with water-sediment characteristics in a hypereutrophic shallow lake, China. Journal of Geophysical Research-Biogeosciences 112, G01005. doi:10.1029/2005JG000129.

Williams, E.J., Guenther, A., Fehsenfeld, F.C., 1992. An inventory of nitric-oxide emissions from soils in the united-states. Journal of Geophysical ResearchAtmospheres 97, 7511-7519.

Xiong, Z., Xie, Y., Xing, G., Zhu, Z., Butenhoff, C., 2006. Measurements of nitrous oxide emissions from vegetable production in China. Atmospheric Environment 40, 2225-2234.

Yan, X.Y., Akimoto, H., Ohara, T., 2003. Estimation of nitrous oxide, nitric oxide and ammonia emissions from croplands in East, Southeast and South Asia. Global Change Biology 9, 1080-1096.

Yienger, J.J., Levy, H., 1995. Empirical-model of global soil-biogenic nox emissions Journal of Geophysical Research-Atmospheres 100, 11447-11464.

Zhang, J., Han, X., 2008. $\mathrm{N}_{2} \mathrm{O}$ emission from the semi-arid ecosystem under mineral fertilizer (urea and superphosphate) and increased precipitation in northern China. Atmospheric Environment 42, 291-302.

Zheng, X.H., Han, S.H., Huang, Y., Wang, Y.S., Wang, M.X., 2004. Re-quantifying the emission factors based on field measurements and estimating the direct $\mathrm{N}_{2} \mathrm{O}$ emission from Chinese croplands. Global Biogeochemical Cycles 18, GB2018. doi:10.1029/2003GB002167.

Zheng, X.H., Huang, Y., Wang, Y.S., Wang, M.X., 2003. Seasonal characteristics of nitric oxide emission from a typical Chinese rice-wheat rotation during the non-waterlogged period. Global Change Biology 9, 219-227.

Zou, J., Huang, Y., Zheng, X., Wang, Y., 2007. Quantifying direct $\mathrm{N}_{2} \mathrm{O}$ emissions in paddy fields during rice growing season in mainland China: dependence on water regime. Atmospheric Environment 41, 8030-8042. 